\title{
DENGAN MENGGUNAKAN MEDIA POTONGAN-POTONGAN KATA DAPAT MENINGKATKAN KETERAMPILAN MEMBACA NYARING DI KELAS I SD NEGERI O5 KABAWETAN
}

\author{
Budi Susanti
}

SD Negeri 05 Kabawetan

\begin{abstract}
Abstrak
Penelitian tindakan kelas ini dilakukan pada siswa kelas I SD Negeri 05 Kabawetan tahun pelajaran 2016/2017. Penelitian ini dilakukan dikarenakan adanya permasalahan yaitu hasil belajar mata pelajaran Bahasa Indonesia khususnya membaca nyaring masih rendah. Melalui media potongan-potongan kata permasalahan ini dicoba untuk diperbaiki dan ditingkatkan. Tujuan Penelitian ini adalah untuk meningkatkan keterampilan membaca nyaring melalui penggunaan media potongan-potongan kata pada siswa kelas $1 \mathrm{SD}$ Negeri 05 Kabawetan tahun pelajaran 2016/2017. Prosedur penelitian ini dilakukan sebanyak dua siklus langkah-langkah dalam setiap siklus terdiri dari empat tahap yaitu tahap perencanaan (planning), pelaksanaan tindakan (acting), pengamatan (observing) dan refleksi (reflecting). Subyek penelitian ini siswa kelas 1 SD Negeri 05 Kabawetan tahun ajaran 2016/2017 dengan jumlah siswa 23 siswa yang terdiri dari 14 siswa laki-laki dan 9 siswa perempuan. Adapun instrumen penilaian yang digunakan adalah tes proses dan tes akhir. Tes proses menggunakan lembar observasi aktifitas belajar siswa, lembar performance, lembar kuisioner siswa dan nilai akhir siswa menggunakan nilai rata-rata dan presentase ketuntasan belajar. Hasil yang diperoleh pada penelitian ini terlihat dari ketertarikan siswa pada kondisi awal nilai hasil belajar 57,39,00 \% menjadi 76,08,00\% pada siklus I meningkat $18,69 \%$ dan menjadi $86,95,00 \%$ pada siklus II meningkat $10,86 \%$. Pada indikator partisipasi aktif siswa dalam proses pembelajaran dari siklus I $63,13 \%$ menjadi $76,73 \%$ pada siklus II meningkat $13,6 \%$, dari pengamatan performance siswa dalam membaca nyaring pada siklus I $53,75 \%$ menjadi $82,00 \%$ pada siklus II meningkat $28,25 \%$ dan dari hasil kuisioner siswa $57,25 \%$ pada siklus I menjadi $81,5 \%$ pada siklus II meningkat 24,25\%. Dapat disimpulkan bahwa dengan menggunakan media potongan-potongan kata dapat meningkatkan keterampilan membaca nyaring di SD Negeri 05 Kabawetan.
\end{abstract}

Kata Kunci : Media Potongan-potongan Kata, Membaca Nyaring, Keterampilan membaca.

\section{PENDAHULUAN}

Fokus utama tujuan pengajaran Bahasa Indonesia meliputi empat aspek keterampilan berbahasa yaitu keterampilan menyimak, keterampilan berbicara, ketrampilan membaca dan menulis. Keempat aspek kemampuan berbahasa tersebut saling berkaitan erat, sehingga merupakan satu kesatuan dan bersifat hirarkis, artinya keterampilan berbahasa yang satu akan mendasari keterampilan berbahasa yang lain. Pembelajaran membaca di kelas I SD merupakan pembelajaran membaca tahap awal, salah satunya adalah membaca nyaring.

Dengan membaca nyaring siswa akan mengenali huruf-huruf dan membacanya sebagai suku kata, kata dan kalimat sederhana. Kemampuan membaca nyaring siswa kelas I SD kebanyakan belum 
mencapai Kriteria Ketuntasan Minimal yang setelah diteteliti dan dicermati ternyata siswa kurang tertarik dan kurang aktif dalam mengikuti pembelajaran membaca nyaring. Upaya meningkatkan kemampuan membaca nyaring merupakan kebutuhan yang mendesak untuk dilakukan. Langkah yang harus ditempuh adalah menyediakan alat peraga kongkrit yaitu media potonganpotongan kata. Media ini memberikan pengalaman kongkrit, meningkatkan motivasi belajar siswa dan mempertinggi daya serap siswa serta siswa dapat memusatkan perhatiannya dalam belajar. Melalui penggunaan media potonganpotongan kata diharapkan taraf kesukaran dan kompleksitas dari pembelajaran Bahasa Indonesia yang memberi pengaruh yang cukup besar dalam proses belajar sehingga hasilnya akan lebih baik.

Di sekolah pembelajaran bahasa Indonesia memiliki peranan yang sangat penting. Seperti yang dikemukakan Akhadiah dalam Darmiyati Zuchdi dan Budiasih (2001:57), bahwa pembelajaran membaca, guru dapat berbuat banyak dalam proses

Penelitian tindakan kelas dilakukan di kelas I SD Negeri 05 Kabawetan. Penelitian ini akan dilaksanakan dalam 2 siklus. langkah-langkah dalam setiap siklus terdiri dari empat tahap yaitu tahap perencanaan (planning), pelaksanaan tindakan (acting), pengamatan (observing) dan refleksi (reflecting).

Mulai dari bulan Juli sampai dengan bulan Desember 2016 tahun ajaran 2016/2017. Sesuai dengan jenis data yang diperlukan dan kelas yang diobservasi maka subjek yang diteliti siswa kelas I SD Negeri 05 Kabawetan tahun pelajaran 2016/2017, pengindonesiaan anak-anak Indonesia. Dalam pembelajaran membaca, guru dapat memilih wacana yang berkaitan dengan tokoh nasional, kepahlawanan, kenusantaraan dan kepariwisataan. Selain itu, melalui pembelajaran membaca, guru dapat mengembangkan nilai-nilai moral, kemampuan bernalar dan kreativitas anak didik. Kemampuan membaca nyaring siswa kelas I SD Negeri 05 Kabawetan belum mencapai Kriteria Ketuntasan Minimal yang ditetapkan yaitu sebesar 6,8 dan indikator keberhasilan siswa masih rendah belum mencapai KKM. Dalam membaca nyaring suku kata dan kata dengan lafal yang tepat, nilai rata-rata yang dicapai siswa pada kondisi awal hanya mencapai 57,39\% ini dapat dilihat dari hasil belajar siswa. Dari 23 siswa kelas I SD Negeri 05 Kabawetan Ketika diadakan tes membaca hanya 5 siswa yang baru lancar membaca atau hanya $21,73 \%$ saja siswa yang lancar membaca nyaring. Melihat hasil di atas ternyata aktivitas belajar siswa masih rendah.

\section{METODE}

yang berjumlah 23 orang terdiri dari siswa laki-laki sebanyak 14 orang dan perempuan sebanyak 9 orang.

Langkah-langkah dalam setiap siklus terdiri dari empat tahap yaitu tahap perencanaan (planning), pelaksanaan tindakan (acting), pengamatan (observing) dan refleksi (reflecting). Kemudian setelah suatu siklus selesai diimplementasikan khususnya setelah adanya refleksi, selanjutnya diadakan perencanaan ulang yang dilaksanakan dalam siklus tersendiri atau pada siklus selanjutnya. 


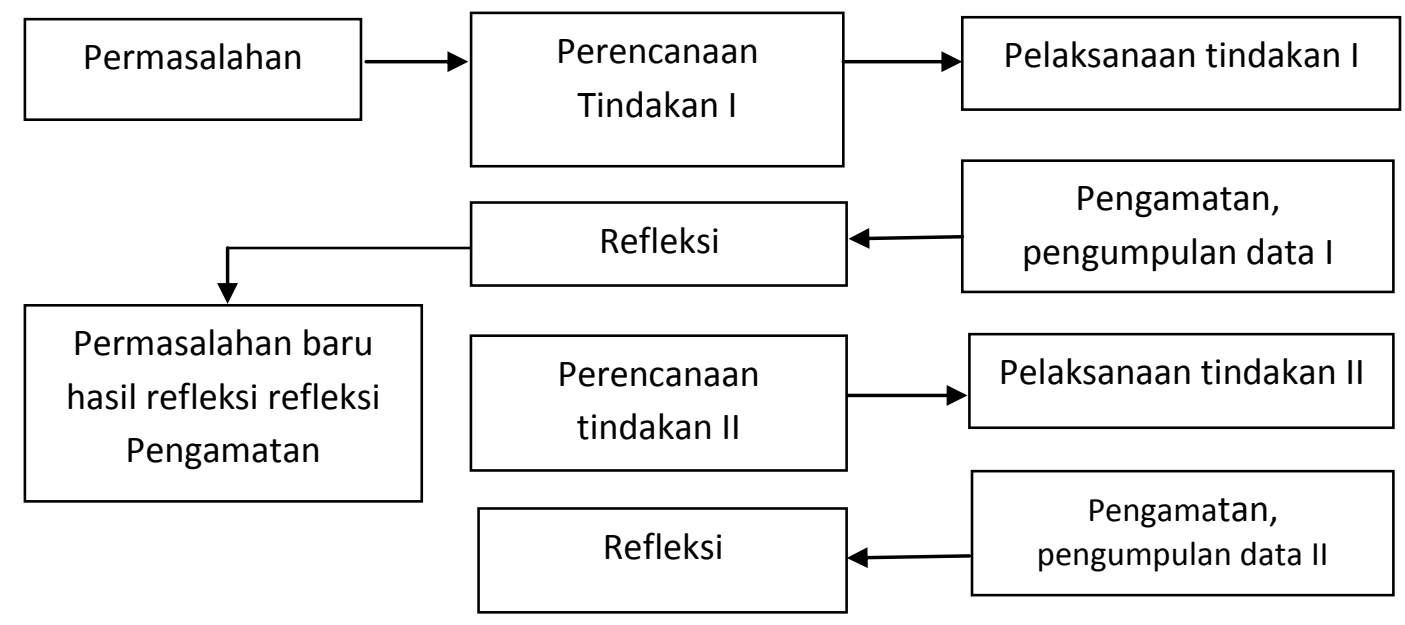

\section{HASIL}

\section{Kondisi Awal}

Setelah peneliti mencermati ternyata siswa kurang tertarik dan kurang aktif dalam mengikuti pembelajaran membaca nyaring. Hal ini disebabkan oleh guru yang dalam pembelajaran membaca nyaring sering menggunakan metode ceramah, sehingga siswa mendapat pemahaman yang masih abstrak. Nilai hasil belajar siswa belum mencapai KKM yang ditetapkan nilai ratarata yang dicapai dari 23 siswa adalah 8 siswa yang mendapat nilai 80,6 siswa mendapatkan nilai 70,4 siswa mendapat nilai 60,3 siswa mendapat nilai 50,2 siswa mendapat nilai 40 .

\section{Siklus I}

\section{Perencanaan}

Guru membuat Rencana Pelaksanaan Pembelajaran (RPP), menyiapkan alat peraga, dan menyiapkan instrument observasi.

\section{Pelaksanaan}

Pada pelaksanaan tindakan kelas siklus ini kegiatan awal sampai akhir penelitian dibantu teman sejawat guna perbaikan lebih lanjut pada siklus berikutnya.

Kegiatan pembelajaran sebagai berikut :

1. Kegiatan awal.
Tahap Kegiatan awal/apersepsi, guru memotivasi siswa untuk aktif dalam pembelajaran dengan melakukan :

a. Siswa memperhatikan gambar "Tubuhku"

b. Guru menyuruh siswa menghitung jumlah mata, jumlah telinga, jumlah tangan, jumlah kaki dll.

c. Siswa membaca nama -nama anggota tubuh yang ada dengan bimbingan guru

d. Guru menyiapkan potongan potongan kata

e. Siswa menempelkan kata-kata tentang tubuhku sesuai dengan gambar yang ada, kemudian membacanya..

f. Siswa diminta membaca nama-nama anggota tubuh secara bergantian

g. Guru menyiapkan potongan - potongan kata beberapa set dan siswa menyusunnya sesuai dengan gambar tubuhku

2. Tahap kegiatan inti

a. Siswa mengamati terhadap objek yaitu kartu huruf yang ditempel di papan tulis.

b. Guru memberi contoh dalam membaca nyaring.

c. Siswa membaca nyaring bacaan "Tubuhku" dengan kata yang jelas dan lafal yang tepat secara bersama-sama. 
d. Siswa maju satu persatu membaca nyaring dengan ketentuan-ketentuan tersebut

e. Guru membetulkan bacaan siswa yang belum betul

f. Siswa berpasangan menggeser kata yang telah diacak.

\section{Tahap kegiatan akhir}

Kegiatan yang dilaksanakan meliputi penilaian, refleksi dan tindak lanjut.

\section{Observasi}

Observasi yang dilakukan oleh teman sejawat guru dengan hasil sebagai berikut :

1) Ketertarikan siswa terhadap penggunaan alat peraga Potongan-potongan kata masih rendah.

2) Siswa masih kurang aktif dalam bertanya dan menjawab pertanyaan guru.

3) Siswa dalam membaca nyaring kurang keras sehingga teman yang lain kurang memperhatikan.

4) Pada guru persiapan dan penyediaan alat peraga kurang besar, dan kurang menarik sehingga siswa yang dibelakang kurang jelas.

5) Guru kurang banyak dalam memberikan contoh membaca, sehingga siswa kurang lancar dalam membaca.

Tabel 4.3 Lembar perfomance

\begin{tabular}{|l|c|c|}
\hline Aspek yang dinilai & \multicolumn{2}{|c|}{ Siklus I } \\
\hline & siswa & $\%$ \\
\hline $\begin{array}{l}\text { Kelancaran } \\
\text { membaca }\end{array}$ & 10 & 43 \\
\hline Kejelasan lafal & 10 & 43 \\
\hline Ketepatan intonasi & 10 & 43 \\
\hline Keberanian & 20 & $\mathbf{8 6}$ \\
\hline Rata-rata & & $\mathbf{5 3 , 7 5 \%}$ \\
\hline
\end{tabular}

\section{Refleksi}

Dari hasil pengamatan yang telah dilakukan pada penelitian tindakan kelas maka perlu adanya tindakan perbaikan pada siklus kedua yaitu:

a) Menyediakan alat peraga yang lebih menarik, ukuran media potongan potongans diperbesar, direncanakan anak diajak mengamati gambar - gambar yang disediakan.

b) Memberikan contoh membaca yang lebih banyak kepada siswa dengan berbagai lembaran-lembaran potongan kata agar minat membacanya lebih tinggi dan membacanya dengan suara yang lebih keras.

c) Sebaiknya guru memberikan bimbingan membaca kepada siswa-siswa yang masih

d) mengalami kesulitan dalam membacanya(membaca nyaring)

e) Sebaiknya guru memberikan waktu minimal 15 menit sebelum proses pembelajaran berlangsung yang berguna sebagai pembiasaan membaca siswa

f) Menyusun soal-soal untuk kuesioner setelah pembelajaran.

g) Merencanakan memberikan perhatian khusus kepada 1 siswa yang belum tuntas.

h) Disiapkan pertanyaan-pertanyaan kepada siswa dari pertanyaan yang mudah ke pertanyaan yang sukar.

Tabel 4.4 Lembar Kuisioner Siswa

\begin{tabular}{|l|c|c|}
\hline \multicolumn{1}{|c|}{ Aspek yang dinilai } & \multicolumn{2}{c|}{ Siklus I } \\
\hline & siswa & $\%$ \\
\hline Senang kartu huruf & 23 & 100 \\
\hline Suka membaca & 10 & 43 \\
\hline Berani bertanya pada guru & 10 & 43 \\
\hline $\begin{array}{l}\text { Dapat menjawab } \\
\text { pertanyaan guru }\end{array}$ & 10 & 43 \\
\hline Rata-rata & & $57,25 \%$ \\
\hline
\end{tabular}


Tabel 4.5 Hasil penilaian siklus I

\begin{tabular}{|c|l|c|c|c|c|}
\hline No & Nilai pencapaian Hasil belajar & \multicolumn{2}{|c|}{ Kondisi awal } & \multicolumn{2}{c|}{ Siklus I } \\
\hline & & Siswa & $\%$ & Siswa & $\%$ \\
\hline 1 & $10-19$ & - & - & - & - \\
\hline 2 & $20-29$ & - & - & - & - \\
\hline 3 & $30-39$ & 2 & 8,0 & - & - \\
\hline 4 & $40-49$ & 5 & 21 & - & - \\
\hline 5 & $50-59$ & 4 & 17 & 1 & 0,4 \\
\hline 6 & $60-69$ & 3 & 13 & 4 & 17 \\
\hline 7 & $70-79$ & 4 & 17 & 4 & 17 \\
\hline 8 & $80-89$ & 5 & 21 & 8 & 34 \\
\hline 9 & $90-99$ & - & - & 6 & 26 \\
\hline 10 & 100 & - & - & - & - \\
\hline & & & & & \\
\hline & Nilai terendah & 30 & & 40 & \\
\hline & Nilai tertinggi & 80 & & 90 & \\
\hline & Prosentase tuntas & 39 & & 78 & \\
\hline & Prosentase belum tuntas & 60 & & 21 & \\
\hline & & 57,39 & & 76,08 & \\
\hline & Nilai rata-rata kelas & & & & \\
\hline
\end{tabular}

Tabel 4.6 Lembar Refleksi Kegiatan Pembelajaran

\begin{tabular}{|c|l|c|c|c|c|}
\hline No & \multicolumn{1}{|c|}{ Aspek Yang Dinilai } & \multicolumn{2}{|c|}{ Kondisi Awal } & \multicolumn{2}{c|}{ Siklus I } \\
\cline { 3 - 6 } & & Siswa & $\%$ & Siswa & $\%$ \\
\hline 1 & Tertarik atau bersemangat & 10 & 43 & 15 & 65 \\
\hline 2 & $\begin{array}{l}\text { Cukup tertatrik atau cukup } \\
\text { bergairah }\end{array}$ & 8 & 34 & 5 & 30 \\
\hline 3 & $\begin{array}{l}\text { Kurang tertarik atau kurang } \\
\text { bergairah }\end{array}$ & 5 & 21 & 3 & 13 \\
\hline
\end{tabular}

Hasil analisis dan refleksi membuka pembelajaran, kegiatan inti, dan menunjukkan bahwa ketertarikan siswa kelas kegiatan akhir atau penutup mengalami I (satu) dalam belajar membaca nyaring dengan potongan-potongan kata mengalami peningkatan, pada kondisi awal $43 \%$ menjadi $65 \%$ pada siklus I berarti naik $22 \%$. Kemampuan guru dalam menerapkan membaca nyaring dengan media potonganpotongan kata pada saat pra pembelajaran, peningkatan .

Hasil belajar siswa pada tes akhir atau pada ulangan harian mengalami peningkatan prosentase siswa tuntas belajar pada kondisi awal rata-rata 57,39 \% dan pada siklus I rata-rata kelas $76,08 \%$. Berarti pada siklus I naik $18,39 \% \%$. Performance siswa 
pada siklus I rata-rata $53,7 \%$, Kuisioner siswa rata-rata $57,25 \%$, Keaktifan siswa dalam pembelajaran rata- rata $65 \%$ indikator keberhasilan penelitian ini hasil belajar diharapkan

mencapai KKM 68.00 dan jumlah siswa tuntas mencapai $78,26 \%$ Hasil yang dicapai rata- rata kelas baik, telah mencapai $76,08 \%$ namun jumlah siswa yang tuntas belajar baru mencapai 28 siswa berarti ada 5 siswa yang belum tuntas dalam KKM atau 21,17\% lagi siswa yang berada di bawah KKM , maka dilanjutkan pada siklus II.

\section{Siklus II}

\section{Perencanaan}

1. pelaksanan dari perencanaan tindakan yang telah disusun yaitu RPP yang telah diperbaiki dan disempurnakan, sehingga kekurangan pada siklus 1 dapat diperbaiki.

\section{Pelaksanaan Tindakan}

Tahap pelaksanaan pada hari Senin, 7 November 2016 Tema 1 Sub tema 2 Pembelajaran 3 Bahasa Indonesia.

1) Tahap Kegiatan awal

a. apersepsi, guru memotivasi siswa untuk aktif dalam pembelajaran,

b. Siswa menyanyikan lagu "Namanama jari" sambil tepuk tangan,

c. Guru menyuruh siswa menghitung Jumlah jari nya,

d. Guru menempelkan potonganpotongan kata berwarna-warni dengan ukuran yang lebih besar,

e. Siswa diminta untuk membaca potongan-potongan kata yang ada.
2) Tahap kegiatan inti

Pembelajaran yang dilakukan selama kurang lebih 40 menit, kegiatan tersebut adalah :

a) Siswa mengamati terhadap objek yaitu kartu huruf yang ditempel di papan tulis.

b) Guru memberi contoh frekuensi dalam membaca nyaring lebih banyak

c) Siswa membaca nyaring bacaan "Nama-nama jari" dengan kata yang jelas dan lafal yang tepat secara bersama-sama.

d) Siswa maju satu persatu membaca syaring dengan ketentuan-ketentuan tersebut

e) Guru membetulkan bacaan siswa yang belum betul.

f) Siswa berpasangan menggeser kata yang telah diacak.

g) Guru memberikan contoh kata-kata lain untuk dibaca siswa

h) Setiap kelompok menyusun katakata yang telah ditentukan guru menjadi kalimat,guru akan memberikan motifasi bagi kelompok yang tercepat menyusun dan kemudian membacanya

3) Tahap kegiatan akhir dilakukan dalam waktu kurang lebih 15 menit.

Kegiatan yang dilaksanakan meliputi penilaian, refleksi dan tindak lanjut. Pada kegiatan penilaian ini prosedur digunakan tes proses dari tes akhir. Instrumen penilaianya soal evaluasi individu dan lembar penilaian. Kegiatan refleksi pelaksanaan membaca nyaring 


\section{Observasi}

Observasi yang dilakukan oleh teman sejawat guru dengan hasil sebagai berikut :

a) Pada kegiatan awal siswa aktif dan bersemangat dalam mengikuti pembelajaran.

b) Ketika siswa disuruh membaca media potongan-potongan kata siswa sangat berantusias sekali ,apalagi ketika siswa secara berkelompok siswa berlomba menyusun potongan -potongan kata tersebut dan kelompok yang tercepat langsung membacanya dengan suara nyaring.

c) Pada siklus II ini hanya ada 1orang siswa yang belum tuntas ,hal ini disebabkan siswa tersebut mempunyai kekurangan.

d) Hasil belajar siswa yang dilihat mulai dari performance, kuisioner, kegiatan pembelajaran ,ketertarikan siswa terhadap membaca nyaring ,dan hasil

akhir pembelajaran menunjukan peningkatan .

\section{Refleksi}

a) Pada kegiatan awal guru harus memberikan apersepsi, memotifasi dan menciptakan suasana kelas dalam pembelajaran yang menyenangkan .

b) Guru harus menggunakan media belajar yang membangkitkan minat membaca bagi siswa kelas I yang sesuai.

c) Sebaiknya siswa dibentuk dalam kegiatan kelompok karena dengan berkelompok siswa bisa bekerja sama .

d) Dengan media potongan-potongan kata dapat mempermudah cara pengajaran membaca nyaring pada siswa kelas I.

e) Keihklasan, kesabaran, dan kasih sayang merupakan kunci sukses keberhasilan membaca nyaring di kelas I .

Adapun data hasil penelitian pada

Tabel 4.10

\section{Lembar performance}

\begin{tabular}{|l|c|c|c|c|c|}
\hline \multicolumn{1}{|c|}{ Aspek yang dinilai } & \multicolumn{2}{c|}{ Siklus I } & \multicolumn{2}{c|}{ Siklus II } & $\begin{array}{c}\text { Jml } \\
\text { siswa }\end{array}$ \\
\hline & siswa & $\%$ & siswa & $\%$ & 23 \\
\hline Kelancaran membaca & 10 & 43 & 18 & 78 & \\
\hline Kejelasan lafal & 10 & 43 & 18 & 78 & \\
\hline Ketepatan intonasi & 10 & 43 & 15 & 65 & \\
\hline Keberanian & 20 & 86 & 18 & 78 & \\
\hline \multicolumn{1}{|c|}{ Rata-rata } & & & & & \\
\hline & & $53,75 \%$ & & $82 \%$ & \\
\hline
\end{tabular}

Tabel 4.11

Lembar Kuisioner Siswa

\begin{tabular}{|c|c|c|c|c|c|}
\hline $\begin{array}{c}\text { Aspek yang } \\
\text { dinilai }\end{array}$ & \multicolumn{2}{|c|}{ Siklus I } & \multicolumn{2}{c|}{ Siklus II } & $\begin{array}{c}\text { Jml } \\
\text { siswa }\end{array}$ \\
\hline & siswa & $\%$ & siswa & $\%$ & 23 \\
\hline $\begin{array}{l}\text { Senang kartu } \\
\text { huruf }\end{array}$ & 23 & 100 & 23 & 100 & \\
\hline
\end{tabular}




\begin{tabular}{|l|c|c|c|c|c|}
\hline Suka membaca & 10 & 43 & 18 & 78 & \\
\hline $\begin{array}{l}\text { Berani bertanya } \\
\text { pada guru }\end{array}$ & 10 & 43 & 16 & 74 & \\
\hline $\begin{array}{l}\text { Dapat menjawab } \\
\text { pertanyaan guru }\end{array}$ & 10 & 43 & 16 & 74 & \\
\hline Rata-rata & & $\begin{array}{c}57,25 \\
\%\end{array}$ & & $\mathbf{8 1 , 5 \%}$ & \\
\hline
\end{tabular}

Tabel 4.12

Lembar Tingkat Pencapaian Hasil Belajar Siswa.

\begin{tabular}{|c|c|c|c|c|c|c|c|c|}
\hline \multirow[t]{2}{*}{ No } & \multirow[t]{2}{*}{$\begin{array}{c}\text { Nilai dari aspek } \\
\text { pencapaian hasil belajar }\end{array}$} & \multicolumn{2}{|c|}{$\begin{array}{l}\text { Kondisi } \\
\text { Awal }\end{array}$} & \multicolumn{2}{|c|}{ Siklus I } & \multicolumn{2}{|c|}{ Siklus II } & \multirow[t]{2}{*}{ Ket } \\
\hline & & $\mathrm{S}$ & $\%$ & $\mathrm{~S}$ & $\%$ & $\mathrm{~S}$ & $\%$ & \\
\hline 1 & $10-19$ & - & - & - & - & - & - & \\
\hline 2 & $20-29$ & - & - & - & - & - & - & \\
\hline 3 & $30-39$ & 2 & 0,8 & - & - & - & - & \\
\hline 4 & $40-49$ & 5 & 21 & - & - & - & - & \\
\hline 5 & $50-59$ & 4 & 17 & 1 & 4,0 & 1 & 4,0 & \\
\hline 6 & $60-69$ & 3 & 13 & 4 & 17 & 1 & 4,0 & \\
\hline 7 & $70-79$ & 4 & 17 & 4 & 17 & 1 & 4,0 & \\
\hline 8 & $80-89$ & 5 & 21 & 8 & 34 & 4 & 42 & \\
\hline 9 & $90-99$ & - & - & 6 & 26 & 10 & 43 & \\
\hline 10 & 100 & - & - & - & - & 6 & 26 & \\
\hline & Nilai terendah & 30 & & 40 & & 50 & & \\
\hline & Nilai tertinggi & 80 & & 90 & & 100 & & \\
\hline & Prosentase tuntas & 39 & & 78 & & 91 & & \\
\hline & Prosentase belum tuntas & 60 & & 21 & & 8,0 & & \\
\hline & Nilai rata-rata kelas & 57,39 & & 76,08 & & 86,95 & & \\
\hline
\end{tabular}

Tabel 4.13

Lembar Refleksi Kegiatan Pembelajaran

\begin{tabular}{|c|c|c|c|c|c|c|c|c|}
\hline \multirow[t]{2}{*}{$\mathrm{NO}$} & \multirow[t]{2}{*}{$\begin{array}{c}\text { ASPEK YANG } \\
\text { DINILAI }\end{array}$} & \multicolumn{2}{|c|}{$\begin{array}{c}\text { KONDISI } \\
\text { AWAL }\end{array}$} & \multicolumn{2}{|c|}{ SIKLUS I } & \multicolumn{2}{|c|}{ SIKLUS II } & $\begin{array}{l}\text { Jml } \\
\text { siswa }\end{array}$ \\
\hline & & Siswa & $\%$ & Siswa & $\%$ & Siswa & $\%$ & 23 \\
\hline 1 & $\begin{array}{l}\text { Tertarik atau } \\
\text { bersemangat }\end{array}$ & 10 & 43 & 15 & 65 & 20 & 87 & \\
\hline
\end{tabular}




\begin{tabular}{|l|l|c|c|c|c|c|c|c|}
\hline 2 & $\begin{array}{l}\text { Cukup tertarik atau } \\
\text { cukup bergairah }\end{array}$ & 8 & 34 & 7 & 30 & 3 & 13 & \\
\hline 3 & $\begin{array}{l}\text { Kurang tertarik atau } \\
\text { kurang bergairah }\end{array}$ & 5 & 21 & 3 & 13 & 0 & 0 & \\
\hline
\end{tabular}

\section{Refleksi}

Melihat hasil observasi ketertarikan siswa kelas I (satu) dalam belajar membaca nyaring dengan potongan-potongan kata mengalami peningkatan, pada kondisi awal $57,39 \%$ menjadi $76,08 \%$ pada siklus I berarti naik $18,69 \%$ dan menjadi $86,95 \%$ pada siklus II berarti naik $10,87 \%$. Pada indikator partisipasi aktif siswa dalam proses pembelajaran meningkat dari awal $52,63 \%$ menjadi $63,13 \%$, Dari awal ke siklus I naik 10,5\%. Pada siklus II terjadi kenaikan 13,6\% yaitu dari siklus I 52,63\% ke siklus II (dua), $76,73 \%$. Dari pengamatan performance siswa dalam membaca nyaring kelompok pada siklus I $53,75 \%$ menjadi $82 \%$ pada siklus II (dua) dan mengalami kenaikan $28,25 \%$ dan dari hasil kuesioner siswa $57,25 \%$ pada siklus I menjadi $81,5 \%$ pada siklus II meningkat $24,25 \%$.

Indikator keberhasilan tentang keaktifan dan kemampuan siswa dalam memecahkan masalah pada penelitian ini $86,95 \%$ jumlah siswa berarti telah berhasil. Hal ini diamati pada proses yang menghidupkan suasana pembelajaran sehingga siswa pun mampu memecahkan masalah. Kemampuan guru dalam menerapkan membaca nyaring dengan media potongan-potongan kata. Pada saat pra pembelajaran, membuka pembelajaran, kegiatan inti, dan kegiatan akhir atau penutup mengalami peningkatan dan hasil belajar yang memuaskan.

\section{DAFTAR PUSTAKA}

Anton M.Moeliono.1998.Psikologi Belajar. Yogyakarta:Rineka Cipta.

Darmiyati Zuchdi dan Budiasih.2001.Pendidikan Bahasa dan Sastra di Kelas Rendah. Yogyakarta: PAS.

Guntur Tarigan, Henry. 1979. Membaca sebagai Suatu Keterampilan Berbahasa. Bandung : Angkasa.

Muhibin Syah.1995. Psikologi Pendidikan Suatu Pendekatan Baru. Bandung: Rosdakarya.

Mulyani Sumantri dan Johan Permana. 1999. Strategi Belajar mengajar. Jakarta : Dirjen Dikti

Mulyani Sumantri dan Johan Permana. 2001. Strategi Belajar Mengajar. Bandung: CV. Maulana.

ST. Y. Slamet Kemampuan. 1997. Kemampuan Membaca Pemahaman Mahasiswa ditinjau dari Penguasaan Struktur Kalimat dan Pengetahuan Derivasi.Tesis 